MT-DP - 2015/39

\title{
Are CEE states successful as venture capitalists?
}

JUDIT KARSAI 
Discussion papers

MT-DP - 2015/39

Institute of Economics, Centre for Economic and Regional Studies, Hungarian Academy of Sciences

KTI/IE Discussion Papers are circulated to promote discussion and provoque comments. Any references to discussion papers should clearly state that the paper is preliminary. Materials published in this series may subject to further publication.

Are CEE states successful as venture capitalists?

\author{
Author: \\ Judit Karsai \\ senior research fellow \\ Institute of Economics - Centre for Economic and Regional Studies \\ Hungarian Academy of Sciences \\ e-mail: karsai.judit@krtk.mta.hu
}

July 2015

ISBN $978-615-5594-02-1$
ISSN $1785377 \mathrm{X}$ 


\title{
Are CEE states successful as venture capitalists?
}

\author{
Judit Karsai
}

\section{Abstract}

The entire venture capital sector of Central and Eastern Europe is characterised by the increased weight of state resources. The strengthening of public activities is mainly due to the new type of equity schemes introduced in the European Union's 2007 to 2013 programming period, which allowed the countries in the region to use part of the Structural Funds to develop their venture capital sector. More than 60 venture capital funds undertook to invest more than EUR one billion by the end of 2015, by raising one third of the funds from private investors. The paper examines how successful the CEE EU Member States, with a relatively less developed venture capital industry, were in using government equity schemes based on market cooperation between the state and market actors. Since, due to the shortness of the time elapsed since launching these schemes, the success of the companies financed by such hybrid venture capital funds cannot be assessed, this paper primarily aims to analyse whether the region was able to utilise the past lessons from government equity schemes in countries with a more developed venture capital industry. Similarly to the equity programs applied in the West, the government venture capital programs in the region are also characterised by the short time frame, the mass of administrative requirements tying the hands of investors, the small fund size, which prevents efficient operation, and the limited participation of institutional investors amongst private investors. Compared to developed countries, the unjustified level of benefits to and non-transparent selection of private fund managers and the immaturity of the investment proposals constitute disadvantages in the region. However, the greatest risk of public equity schemes, i.e. the crowding out effect on private investors, is missing in the CEE region due to the lack of market investors.

Keywords: venture capital, government venture capital, government equity schemes, SME finance, Central and Eastern Europe.

JEL classification: G23, G24, G28, M13

Acknowledgement: Financial support from the Hungarian Science Research Fund (OTKA), grant no. K 105581 is gratefully acknowledged. 


\title{
Milyen kockázati tőkés a közép-kelet-európai állam?
}

\author{
Karsai Judit
}

\section{Összefoglaló}

Az állami források megnövekedett súlya az egész közép-kelet-európai régió kockázatitőkeágazatára jellemző. Az állami szerepvállalás felpörgése főként az Európai Unió 2007-2013-as tervezési időszakában bevezetett új típusú tőkebefektetési konstrukcióknak köszönhető, amelyek lehetővé tették, hogy a régió országai a strukturális alapok egy részét kockázatitőkeágazatuk fejlesztésére fordíthassák. A régióban több mint 6o kockázatitőke-alap több mint 1 milliárd euró összegű tőke befektetését vállalta 2015 végéig, mégpedig úgy, hogy a tőke egyharmadát privát befektetőktől gyüjti össze. A tanulmány azt vizsgálja, hogy a relatíve fejletlenebb kockázatitőke-iparral rendelkező közép-kelet-európai uniós országok mennyire sikeresen tudták alkalmazni az állam és az üzleti szféra piaci együttmúködésén alapuló kormányzati tőkeprogramokat. Mivel e hibrid kockázatitőke-alapok által finanszírozott cégek eredményessége a programok indulása óta eltelt idő rövidsége miatt még nem ítélhető meg, a tanulmány elsősorban azt elemzi, hogy a térségben sikerült-e hasznosítani a fejlettebb kockázatitőke-ágazattal rendelkező országok állami tőkeprogramjainak korábbi tapasztalatait. A nyugaton alkalmazott tőkeprogramokhoz hasonlóan a régióbeli konstrukciókra is jellemző a rendelkezésre álló idő rövidsége, a befektetők kezét megkötő adminisztratív előírások sokasága, a gazdaságos múködést akadályozó kis alapméret, valamint a privát befektetők közül az intézményi befektetők korlátozott részvétele. A fejlett országokhoz képest a régióban hátrányt jelent a privát alapkezelők indokolatlan mértékü kedvezményezése és nem transzparens kiválasztása, továbbá a befektetési ajánlatok éretlensége. Ugyanakkor az állami tőkeprogramok egyik legnagyobb veszélye - a privát befektetőket kiszorító hatás - a közép-kelet-európai régióban nem merül fel a piaci befektetők hiánya következtében.

Tárgyszavak: kockázati tőke, kormányzati kockázati tőke, állami tőkeprogramok, KKV finanszírozás, Közép-Kelet-Európa

JEL kód: G23, G24, G28, M13

Köszönetnyilvánítás: A cikk az OTKA K105581 számú pályázat támogatásával készült. 


\section{INTRODUCTION}

Venture capital has an important role to play both in promoting innovation and facilitating access to financing for small and medium size companies. Considering that market funds flowing into the venture capital sector have dropped as a result of the 2008 economic crisis, the importance of government participation in the capital supply of venture capital funds has increased in the EU as a whole and in particular in the Central Eastern European countries ${ }^{1}$. The objective of these schemes was to support the financing of technologically advanced start-ups and early stage companies with great growth potential but no access to financing; at the same time, governments expected the less developed regions to catch up and new jobs to be created, and intended to promote the development of the venture capital sector itself in this way.

This paper restricts itself to examine only venture capital related public action where the government acts an investor in the capital supply of the venture capital market. It intends to contribute to the ongoing international debate (Colombo et al., 2014; Cumming et al., 2014; Leleux et al., 1998; Lerner 2002, 2009, 2010; Meyer, 2007; Murray et al., 2012) by presenting the experiences gained in the Central Eastern European region. It looks to answer the question of how successful the use of EU funds for venture capital purposes was in the Central Eastern European region, with a less developed venture capital market to begin with, and to what extent the lessons learned from the earlier public equity schemes in countries with more advanced venture capital sector could be exploited.

As regards methodology, this paper uses two approaches. On the one hand, and as an innovation, it complies a database on the fund volumes managed by hybrid venture capital funds in the region, on the basis of the information published by the competent European Union bodies, the national managing authorities, the managers of holding and venture capital funds, and the European and national venture capital associations and advisory bodies. In addition, it looks into the academic and business publications on the venture capital sector in the Central Eastern European region, more precisely on government involvement in venture capital schemes. Consultations with researchers specialised in this topic and interviews prepared with the managers of the affected holding and venture capital funds enabled supplementation and verification of the information acquired from secondary sources. Since, in practice, the completion deadline for venture capital investment

\footnotetext{
${ }^{1}$ This study considers the following EU Member States as belonging into the CEE region ("the region"): Bulgaria, Croatia, Czech Republic, Estonia, Hungary, Latvia, Lithuania, Poland, Romania, Slovakia and Slovenia.
} 
implemented from EU funds between 2007 and 2013 is December 2015, this research, closed in the summer of 2015, could not yet assess the effect of public equity schemes on enterprises.

This paper first presents the techniques the Government uses in participating in funding the venture capital market. It next outlines the pre-2007 background to equity schemes based on public-private cooperation in the region, then it examines government equity schemes launched using EU funds in the region in the 2007-2013 period, with detailed focus on the development of factors in the region that determined the success of equity schemes in countries with developed capital markets. The analysis is completed by summarising the lessons of public venture capital schemes in the CEE region.

\section{FORMS OF PUBLIC PARTICIPATION IN THE VENTURE CAPITAL MARKET}

Government funding gave an impetus to the development of the venture capital industry in numerous countries (Murray, 2007; Cumming, 2009, Wilson and Silva 2013). The question is, however, how successful the operation of public equity schemes in the CEE countries, with a less developed venture capital sector, can be, in view of the traditionally more sizeable state and the more expressly paternalistic relations between the state and economic actors. For inappropriately planned government equity schemes the lack of public venture capital investors' expertise, investment strategies influenced by political interests, and the less effective participation in raising up and mentoring the financed companies can cause problems. All these can even lead to crowding out or substitution of private market actors in the venture capital market (Brander et al., 2008; Cumming et al., 2014; Armour and Cumming, 2006; Cumming and MacIntosh, 2006).

There are two basic forms of public participation in funding the venture capital market. The direct solution is to establish state-owned venture capital funds managed by state-owned or state engaged fund managers. In this case, the government uses a hands-on approach, i.e. sets up a venture capital fund owned by a public body, and the state's agent is responsible, as fund manager, for the selection of companies in the portfolio and to make investment decisions. In Central Eastern Europe, state participation in the venture capital market both as owner and fund manager is a widely used solution (Karsai, 2003, 2010, 2013).

In its indirect public participation, the government increases the capital of venture capital funds, otherwise independent from the state and managed by private fund managers. In this case, the government delegates the implementation responsibilities to private fund managers, while the government itself, as one of the investors, acts with specific objectives in mind. These objectives can include, apart from yield expectations, the development of certain 
regions, job creation, or the promotion of innovation. Currently, this indirect form of public venture capital market involvement dominates (Wilson and Silva, 2013; Wilson, 2015). This solution might be suitable, with the involvement of private investors, for establishing the market for seed financing or early stage investments through increasing funding sources, and at the same time it can contribute to gaining the professional expertise of the actors in the sector.

Indirect public participation can be implemented using several techniques. In addition to individual funding to private venture capital funds, the government can invest in the form of a so-called fund of funds into private venture capital funds. In this latter case a state holding fund is established using public funds, and funds with private investors can tender for capital from this fund. In allocating public funds, the (state) manager of this holding fund finances only funds that commit in their investment policy to meeting targets that are relevant for the government, such as financing young firms with significant growth potential (Murray, 2007).

Government participation in private venture capital funds can take place subject to the same terms and conditions as with private investors, i.e. pari passu. In such cases the state receives its share from the investment yield and bears the consequences of loss-making investments, in the same way as other investors in the fund. At the same time, in order to attract private investors, they can be offered more favourable conditions than those of the state actor. For example, private investors can be offered a higher proportion of the yield than their share or be required to bear a smaller proportion of the losses. Via these asymmetric terms, the benefits provided for private financing entities serve the promotion of investments important for the government, such as compensation for the higher risk and lower return on seed capital or early stage financing or investments in less development regions. In the 2007/2013 planning period of the EU, the resources made available for CEE countries to promote venture capital financing enabled the launch of equity schemes based on indirect public participation, where the preferential terms afforded to private investors aimed to generate interest in financing innovative, young companies.

\section{EU PROGRAMMES FINANCING PUBLIC VENTURE CAPITAL SCHEMES}

For the venture capital schemes in the region the EU funds in the 2007/2013 period were partly provided from the Competitiveness and Innovation Framework Programme (CIP), and partly from the European Regional Development Fund (ERDF) framework programme. The former represented the main source of financial assets for investing venture capital at $E U$ level, while one part of the funding available under the latter could be used by the Member State managing authorities as financial engineering instrument. In some of the Member 
States, the so-called Joint European Resources for Micro and Medium Enterprises Scheme, the JEREMIE scheme, was implemented using the holding structure. The holding fund management was carried out by either national or regional institutions, in numerous cases engaging the European Investment Fund (EIF) in the management of those funds (EC, 2O11). While the CIP operated at the level of EU countries, the JEREMIE initiative could be applied at regional level. The JEREMIE programme was basically a supplementary initiative in addition to the CIP programme of the EU. The financial engineering instrument offered by the JEREMIE programme enabled both old and new EU Member States to invest part of the Structural Funds into venture capital, as recoverable funds However, the venture capital made up only a very small proportion of the JEREMIE programme; the loans and guarantees that could be provided under the programme were much more significant $(E I F, 2014)$. The venture capital was not even part of the financial engineering instruments in all participant countries and regions in the JEREMIE programme.

In the region, the JEREMIE programme launched in 2005 was the first EU programme that actually provided the theoretical opportunity for CEE countries, which joined the EU as of 2004 in several stages, to use community funding, in this case a portion of the Structural Funds, to develop their venture capital sector. Before the launch of this programme, the EIF offered to conduct a study free of charge for the interested countries and regions on the current equity position of the given country that could be the basis for the assessment of venture needs (KPMG, 2011). Actually, the so-called gap analyses were completed very slowly. There were places where the content of the analyses was not accepted with satisfaction (such as in Poland), and in some occasions the content of the analysis was simply ignored when developing operational programmes (for example in Hungary) (European Court of Auditors, 2012).

The EIF also made a proposal to manage holding funds, with reference to its experience in the fund of funds scheme for venture capital funds. In countries where the venture capital market was relatively undeveloped and authorities had no relevant experience, such as in Bulgaria, Latvia, Lithuania, Romania and Slovakia, the proposal from the EIF was accepted. However, countries with some previous experience with public equity schemes created public bodies suitable for the management of holding funds instead. According to the picture obtained from the background interviews, the relatively high management fee charged, the perceived difficulties in consultation due to the foreign headquarters, the lack of local knowledge and, presumably, the fact that it would have meant less freedom for the authorities to select venture capital fund managers, were all mentioned as arguments against the engagement of the EIF.

It was not only the JEREMIE programme that provided the opportunity to establish a holding fund from EU resources in the framework of national operational programmes that 
launched tenders for private investors in a fund of funds scheme to establish a joint venture capital fund for private investors. An example of this latter is the Polish National Capital Fund (NCF).

The public funds were channelled into joint venture capital funds, financed from both the national operational programmes and by private investors, or to co-finance venture capital funds with no private investors. In addition to this, it was also possible in the JEREMIE arrangement to create several regional holding funds within a country. ${ }^{2}$

Due to the divergent data collection objectives by the numerous European and national institutions, it is rather difficult to form a comprehensive picture of the capital actually raised and invested by venture capital funds under public equity schemes and the magnitude of public participation in them. The aggregate statistical data for the EU (European Union, 2014) show that, despite the various EU programmes, only a very small proportion was used by the authorities to finance venture capital. In the period between 2007 and 2013, according to the situation at the end of 2013, public resources used for venture capital funds in CEE countries made up only $6 \%$ of the value of the operational programmes, while the funds have so far used less than $60 \%$ of the allocations.

The magnitude of the public equity schemes between 2007 and 2013 in the region can be estimated on the basis of data manually collected by the author from the websites of national managing authorities, ministries, holding fund managers, and academic papers on venture capital sector. (See Table below!)

According to this, by the end of 2015, the 64 venture capital funds established in the region, financed by public participation, allow the investment of some EUR 1.1 billion. The "public" contribution had to include at least $15 \%$ of national funding, in addition to EU funding. Public sector contribution made up more than two-thirds of funds available for investment under the equity schemes between 2007 and 2013. The leverage effect of public funding is shown by the fact that it allowed a total of EUR 400 million in private capital to be raised in the venture capital market of the region. The greatest number of JEREMIE venture capital funds (28), with the highest amount in the region, more than EUR 440 million, had been established in Hungary. Capital commitments from private sectors investors make up $30 \%$ of the Hungarian venture capital funds' resources, since the entire territory of Hungary is classified as an assisted region within the EU. The second highest number of hybrid funds have been created in Poland: here half of the resources of 16 venture capital funds, managing an estimated EUR 380 million capital, originate in the private sector. The third highest number of funds was established in Slovenia, at the same time the number of venture capital funds established in Bulgaria, Latvia, Lithuania, Romania and Slovakia hardly reached five in

${ }^{2}$ In Poland, a holding fund was established in several regions under the JEREMIE programme; however, only two of them launched tenders in 2014 for the managers of venture capital funds. 
each country. In Estonia and Czech Republic, the authorities did not wish to exploit the opportunities offered by the JEREMIE initiative; in Croatia no public equity schemes have been started on account of the short time since its accession to the EU.

Table

Features of venture capital funds financed under public equity schemes in the countries of the CEE region, 2007 to 2013 (items, Million EUR)

\begin{tabular}{|c|c|c|c|c|}
\hline \multirow[t]{2}{*}{ Country } & \multirow{2}{*}{$\begin{array}{l}\text { Number of } \\
\text { funds }\end{array}$} & \multirow{2}{*}{$\begin{array}{l}\text { Capital } \\
\text { managed by } \\
\text { the funds }\end{array}$} & \multicolumn{2}{|c|}{ From the managed capital: } \\
\hline & & & Public funds & Private funds \\
\hline Bulgaria & 2 & 21 & 21 & $\mathbf{O}$ \\
\hline Croatia & O & O & о & O \\
\hline Czech Republic & $\mathbf{0}$ & $\mathbf{0}$ & $\mathbf{o}$ & $\mathbf{0}$ \\
\hline Estonia & O & $\mathbf{0}$ & $\mathbf{o}$ & $\mathbf{0}$ \\
\hline Hungary & 28 & 443 & 310 & 133 \\
\hline Latvia & 3 & 39 & 27 & 12 \\
\hline Lithuania & 5 & 70 & 53 & 17 \\
\hline Poland & 16 & 380 & 190 & 190 \\
\hline Romania & $\mathbf{1}$ & 18 & 10 & 8 \\
\hline Slovakia & 2 & 47 & 35 & 12 \\
\hline Slovenia & 7 & 69 & 34 & 35 \\
\hline Total CEE & 64 & 1087 & 680 & 407 \\
\hline
\end{tabular}

Comment: For Poland, funds were financed similarly to the JEREMIE programme but under a different arrangement. Polish data are based on estimates.

Source: Own collection by the author, on the basis of websites of organisations managing public schemes and holding funds, and academic papers on venture capital sector. 


\section{BACKGROUND TO THE PRIVATE/PUBLIC CAPITAL COOPERATION}

Before the funding that could be applied for from the European Union from 2007 onwards, there were a few pilot projects to promote public/private venture capital market cooperation in the countries of the region. These projects also offered a practising ground and preparation opportunity for local authorities and market actors for subsequent tenders for much higher amounts.

For example, in Poland an organisation investing public funds into private funds as fund of funds and operating as a holding fund was already established in 2005. The National Capital Fund (NCF) established in this manner intended to finance early stage technology companies, but by 2010 had only managed to engage with two venture capital fund managers (Klonowski, 2010, 2011). There was a later failed attempt also in Hungary: a venture capital fund $60 \%$ owned by the private Japanese SBI Holding Inc. and $40 \%$ by the state-owned Hungarian Development Bank (MFB) was established at the end of 2008 under the name SBI Europe Fund. It was managed by ELAN SBI Capital Partners (Binder, 2009). Since, according to the $\mathrm{MFB}$, the operational efficiency of the joint fund was not sufficient, its yield expectations were too high and, from more than 300 assessed projects, it implemented only a single investment, the MFB acquired the share of the Japanese party in 2012 (MTI, 2012). In Estonia, the Estonian Development Fund (EDF), established in 2006, was granted a mandate to purchase minority shareholdings in start-ups with private investors, initially directly, then via a private venture capital fund, Smartcap. The experience of the EDF's operation was positive but the companies in the portfolio gained no major role in the Estonian economy (Kitsing, 2013).

The Latvian venture capital scheme between 2004 and 2006 was indeed already a prototype for the region's later equity schemes. Its application brought forward all the issues the other countries later had to face and also projected the potential benefits that hybrid investments are able to offer. The public owner of the project was the Latvian Guarantee Agency (LGA), and the private contribution came from regional pension funds, international venture capital funds and wealthy private individuals; the public share in ,practice was around 50\% (Mannick, 2007). Instead of the former state controlled allocation mechanism, private sector experts were selected for the asset management. This eliminated the otherwise customary red tape and the lack of market orientation. However, due to its novelty, the drafting of the legal documentation took an extremely long time. The tender for the selection of the venture capital fund's manager attracted an unexpected number of applicants (eight applicants for three positions). The selection of the winners involved huge tension and took a long time. Some of the unsuccessful applicants sought redress from the public procurement 
authorities. The main mistake was the failure to involve the representatives of the venture capital industry in the early development stage of the programme. The profit/loss distribution parameters of the private investor incentive scheme had to be corrected during the notification procedure but before its completion (Mannick, 2007; Avots et al., 2013). According to the researchers assessing the Latvian scheme, a much greater emphasis should have been paid to business training related to venture capital financing. An incubator programme would have been required for high growth companies, in order to broaden the range of companies potentially using venture capital financing. Regular communication and consultation opportunities would also have been needed between investment fund managers and the various stakeholders. However, as a positive effect from the scheme, cooperation between the public authority and the private investors became much more intense (Mannick, 2007).

\section{NOTIFICATION OF VENTURE CAPITAL SCHEMES}

Individual countries had to seek approval from the European Commission for their EUfinanced public equity schemes to apply in the 2007/2013 period, i.e. they had to notify them. This was far from being a routine procedure, since the issue of potential market distortion is particularly valid in connection with the state's participation as an investor in the venture capital market, i.e. whether the venture capital provided to individual businesses qualifies as state aid conferring competitive advantage on those companies. Due to the complexity of this issue, the European Commission issued specific guidelines in 2006 under the title Risk Capital Guidelines, (RCG), and amended them several times due to the change in market circumstances. The requirements to be met by equity schemes have been laid down by the EU in 2009 in a separate set of rules, in the General Block Exemption Regulation (GBER). Both the RCG and the GBER contained expectations for venture capital funds, their managers and companies in receipt of equity investment (EC, 2011; Nicolaides, 2013). ${ }^{3}$

It was expected that the funds to be established have, apart from the government, forprofit private sector owners, and 50\% (in assisted areas 30\%) of investments individually come from private investors. Private investors must have an identical share of the benefits arising from and obligations attached to the investment as public sector investors (incentives to private investors were also allowed in assisted areas). The fund management had to be commercial and the remuneration of fund managers tied to the performance of the fund;

\footnotetext{
3 Amongst others, the Guidelines set out the criteria under which the investors' activity can be considered as for-profit, being a material precondition for the exclusion of prohibited competitive advantage; furthermore, they set the size, age, regional location and sector of the companies that can receive a certain size and type of equity investment without it qualifying as state aid.
} 
fund managers had to be selected in competitive tenders. The funds had to make their investment decision at arm's length, in the possession of a business and exit plan, with an appropriate representation of private investors. The investment volume per company was capped. (It could be EUR 1.5 million in any 12 month period; however, this ceiling was raised to EUR 2.5 million from 2011.) The investment eligibility was different, based on the size, life-cycle and location of the companies concerned.

The importance of this notification procedure was highlighted by the fact that public authorities and investors wishing to participate in their equity schemes and companies in search of venture capital faced for the first time the EU's expectations that were sometimes rather restrictive, at least compared to their domestic practice.

The Hungarian programme for notifying a JEREMIE venture capital programme is a good example of its features and what the competent European authorities actually examined in the approval procedure. In the draft, all cumulative conditions set out in the EU Guidelines on venture capital have been met: 30\% participation by private investors; investment at arm's length; business plan mandatory for each transaction and a realistic exit strategy. What is more, according to the draft, fund managers already had to make a preliminary presentation of the selection and assessment criteria they wished to apply to an application. The programme notification took place in several steps since, as time went by, the managing authority increased the envelope it intended to invest as venture capital. The requirement of commercial management was included through the requirement that fund managers had to operate by seeking to optimise the yield for the investors, and their remuneration consisted of a fixed fee, depending on the fund size, and a performance based success fee. The government as investor was not involved in making investment decisions. Later, the draft was even more clear that fund managers had to be independent from any kind of public influence. The scheme provided for the representation of private investors in the decision making, for example via their participation in the Investors's Committee or the Advisory Committee. However, the state owner of the funds (the holding fund) had a veto or preferential vote on strategic decisions related to the fund's operation, and so, amongst others, on matters related to the reduction of the subscribed capital, buy-back or transfer of ownership of the equity fund units, amendments to the operating policy of the fund and the payment of the yields. When fund managers entered into agreement with the holding fund, they undertook to meet these targets and, if they failed to do so, they had to pay a penalty to the holding fund (European Commission, 2008, 2012, 2013). 


\section{MAIN ELEMENTS OF PUBLIC EQUITY SCHEMES}

Crucial for the success of equity schemes in developed countries were the time frame available for the preparation and implementation of the scheme, the commercial approach in setting the rules for the investments by venture capital funds participating in the scheme, the possibility for the scheme's territorial extension, the appropriate equity volume available for investment, the experience of the actors within the sector, the unbiased selection of private fund managers and incentivisation commensurate with the risks involved, and publicity for the schemes (Karsai, 2014).

\section{Time horizon of public equity schemes}

The launch of the equity schemes was rather lengthy, even according to the EU's own evaluation. The European Commission issued the first comprehensive and relevant explanatory memorandum in February 2011, which helped Member States, by distinguishing the various types of financial engineering instruments, to interpret the regulation of Structural Funds in conjunction with that of financial engineering instruments (European Court of Auditors, 2012). Its absence seriously slowed down the launch of the schemes and aligning the EU funds with the legal requirements of individual facilities. This implies the risk that the volume of investments would fail to reach the envisaged level, since the funds would not have enough time during the term of the schemes to invest all equity available to them (Tillvaxtverket, 2011).

Following the approval of the notification for the capital schemes, the holding funds must first be established. They usually launch tenders in several consecutive years for venture capital fund managers, and in every round the venture capital funds were established only after the completion of the tendering which contracted their managers. After having negotiated the terms of investment, agreed and concluded an agreement, they then made the equity available to the companies concerned in tranches, mainly on security grounds. All these took a lot longer than the time later available for spending the funds, although this is the most important period in the funds' lives. In Latvia, for example, more than half of the JEREMIE programme's time frame was spent on the legal and institutional establishment of the facility, the selection of the intermediary fund managers and setting up the funds, and then publishing the calls (Michie and Wishlade, 2012). In Hungary, where the JEREMIE venture capital programme was first launched in the region, at the end of 2013, the original closing date of the programme, of the altogether 28 funds published in total, ten funds had not been established, mainly due to the repeated licensing to increase the funds' volumes. 
The slowness of notification and, tendering and setting up the funds late put the holding funds and the managers of the venture capital funds under pressure to invest their funds before the final absorption deadline of the Structural Funds, i.e. by the end of 2015, since any unspent funds must be repaid to the European Union. This urgency inevitably can negatively influence the quality of investments: for example, less promising companies may receive the venture capital supplemented by public funds, or less innovative businesses that could possibly raise the required funding from other sources (cf.: Tillvaxtverket, 2011).

\section{Size of venture capital funds}

The equity schemes recommended by the EU to the authorities in the region ignored the finding of the research that the widely held belief that very early stage seed capital investments are to be implemented by small size specialised funds is wrong (Meyer, 2007; Dimov and Murray, 2006). Indeed, in particular in the US, the largest and most experienced venture capital funds implemented the most seed capital investments. The US model for seed capital financing implicitly indicates that seed capital is not viable in the market if used in an isolated way. It should instead be perceived as the first phase of the process during which a successful company gets through several investment rounds till the exit of the investor. As such, US investors engaged in seed capital financing are multi-phase investors and, in their case, managing USD one billion in funds is not rare. In these large size funds, the full range of the activities decreases the high risk of the earliest phase (Murray and Lingelbach, 2009). Since, in the venture capital sector, new fund managers' learning and gaining experience is a time-consuming process, due to the funds not performing adequately on these grounds they are not able to enter the market with newer and newer funds. As such, a government policy providing capital to numerous small new funds is necessarily able to have an influence only in the short run. Additionally, the demonstration effect is also negative, i.e. private investors will perceive investment in such funds as excessively risky (Meyer, 2007).

Individual venture capital funds in the countries of the region, financed through holding funds from the EU Structural Funds, managed on average EUR 16 million in equity, as shown in the table compiled by the author. The average base size however covers two different arrangements with different sizes. The size of the so-called co-finance funds is smaller than the average, close to EUR 12 million. These funds work exclusively from government funds and private equity was contributed only to individual investments, in the minimum required proportion. The size of the so-called joint funds, also known as hybrid funds, was on average close to EUR 18 million. In terms of their number and the equity managed, the joint funds accounted for nearly $90 \%$ of the funds. The co-finance funds mainly financed the seed capital phase, and their size was smaller to begin with, due to the lack of private equity. Co-financing 
capital seed investment funds proved to be less attractive to private investors. This is suggested by the fact that in several countries there were no private applicants to manage seed capital funds. The Hungarian market was an exception; there it was mainly investors tendering for joint growth funds who were interested in joint seed capital funds.

The average EUR 18 million size of the hybrid venture capital funds established in the CEE region with public participation (as shown in the table) shows that funds here are even smaller than the funds established in the more developed countries that already proved to be too small 4 , and so they very probably fail to initiate an economical and self-sustaining operation. A continuing public financing need for venture capital funds financed from public funds can therefore be forecasted for the next programming period.

\section{Investment restrictions in public equity schemes}

Restrictions related to the investment targets for public funds are against the very nature of venture capital, and so rules of this type decrease the success that can be reached (EVCA, 2010). That is, it is impossible to tell in advance in which areas and which sectors an appropriate number of quickly growing companies appear and where significant inventions appear that can be supported by venture capital ( $c f . E C$, 2012). According to the experience in developed countries, the government schemes often sought to promote financing in industries or geographical regions that attracted no capital, leading to a waste of resources.

Another conceptual problem is that the affected venture capital funds can finance companies at a certain development stage or companies of a certain size or age. The schemes can also specify which types of securities the investors can use, and the public arrangements can also influence the future of the companies if acquisitions or secondary equity sales are restricted. These constraints can probably be understandable from the viewpoint of government policy but they go against the process of business. The fact that the objectives of the public and private sectors do not necessarily coincide means an obvious contradiction. A potential pressure exists between the government's social and economic development objectives and the for-profit approach of the private sector. For example, the development of small and medium enterprises and the promotion of innovation is a flagship public objective, while this in only a by-product for private investors who are interested in profit (cf. Mason, 2013)

A typical mistake in the developed countries' government schemes was to prescribe that funding could be awarded only to domestic businesses (Lerner, 2009). It seems to contradict the geographical restrictions on investments that, amongst the venture capital funds

\footnotetext{
4 The size of individual venture capital funds financed by UK regional holding funds was typically
} between GBP 15 to 25 million (Regeneris Consulting Ltd., 2013). 
financing the early stage, primarily those that are perceived by international institutional investors as worth financing can be successful, and on the other hand, the equity coming from public sources can flood the market, which can have detrimental effects on market processes (Lerner, 2009).

Although in the meanwhile the mistakes of earlier public schemes became publicly known, including the negative effects or inefficiency of the restrictions, it seems that these standards, originating in the West and partly proved to be wrong in the meanwhile, have been applied in the government equity schemes implemented in the CEE region.

The use of the Structural Funds precluded investments in foreign companies. Individual governments could have, at the most, some room for manoeuvre in appointing regions eligible for financing within the countries, although this was largely influenced by the assisted or non-assisted status, based on the development of these regions. As regards the purpose of these investments, rules in most countries allowed only investment by capital increase but did not allow acquisitions from existing shareholders. In the field of banned investment purpose use, funds could nowhere use the equity to substitute for loans extended to the companies; moreover, they could not underwrite reorganisations for companies in difficulties. Innovation financing was a priority objective in most countries. In the schemes within the region, the rules on state aid uniformly specified how old the companies in receipt of funding could be and what their sales revenue could be and also excluded certain sectors from financing. Restrictions even covered the amount of equity that could be invested in a company with a single investment decision and how many such decisions could be made per annum.

The restrictive rules have been changed and clarified, even when the schemes were already in progress. For example, in the second round of the Hungarian JEREMIE programme - as a consequence of the related notification procedure - fund managers already selected in the first round could not apply for growth funds, but the same shareholders could apply again by launching a new fund manager, which questioned the purpose of this restriction (Zsembery, 2012).

The problematic nature of the restrictions is well illustrated by an extreme case of a fund in the Latvian JEREMIE scheme. Here the three winners were unable to invest even onethird of the available funding one year before the period available for investment. In particular, one of the funds, financing start-ups, lagged behind its commitments. The fund should have provided follow-up financing for companies already financed by the seed capital fund, set up exclusively from public funds. Additionally, this fund expressly targeted technology companies. All these conditions have tended to restrict the fund's options. It sought to solve this issue by trying to find companies abroad that were ready to register themselves in Latvia and transfer a part of their activities. However, it can be assumed that 
these companies will not remain in the country later on, since their further financing cannot be ensured (Avots et al., 2013).

The majority of the restrictions of the equity schemes in the region were unnecessary, either because the funds themselves would have complied with them in any case or because they circumvented them. A further part of the rules discouraged potential, such as foreign investors or fund managers from cooperating with the state, that could possibly have brought greater benefits than those arising from the restriction.

\section{Incentives to private investors}

Incentives can take the form of distributing the profits after the exit from the transaction between public and private investors or the timing of the public and private contributions and the compensation for possible losses suffered by private investors (Murray, 2007). Tax relief can also be linked with public equity schemes and could further increase the willingness of private investors to join funds within the scheme.

The experience in the region with the arrangements designed to invest public venture capital show a mixed picture. In the Member States of the region where the venture capital sector was relatively developed, a serious interest was taken in investments in joint funds. However, there were funds in several countries that could not be set up after their launch, due to the reluctance of private investors, such as with regard to the Romanian Ascenta Operation and the Latvian Imprimatur funds.

Where authorities used the incentives for private investors, the interest from private fund managers and the private investors behind them was intense, apart from the very small size seed capital funds. The incentive arrangement in the equity scheme offered by the Polish NVC required lower risk taking from and offered higher yields to private investors (Rudnicka and Dietl, 2013). The generated revenue went to the private investors as long as it reached the equity invested. Then, the public holding fund received the equity up to the amount of its investment. In addition to this, the revenue again went to private investors until the pre-set minimum yield was reached, then to the public fund, again until a minimum yield was reached $(K F K, 2011)$. In the Latvian equity scheme, the share of private investors from the success was applicable above the expected $6 \%$ internal rate of return, and in the event of a loss, private investors were the first to receive their equity back (Avots et al., 2013).

In Hungary, the preference of private investors took place in two forms. On the one hand, it was in the form of the upside reward applicable to public investors, which channelled the entire yield exceeding the current reference rate to private sector investors, i.e. public investors were not entitled to the profit in excess of the reference rate. The other 
preference was loss mitigation. Under this rule, the first $5 \%$ of the loss generated was to be borne by public investors only, and further losses by the investors pro rata to their paid up contribution. Later, for the joint growth funds, the loss rate to be borne only by the state was raised from $5 \%$ to $10 \%$, and for seed capital funds from $5 \%$ to $15 \%$. The investors continued to bear losses in excess of these rates pro rata to their equity. The justification for this increase in the state's loss bearing is questioned by the fact that the number of applicants in each tender rounds was far above the possibility provided by the actual tender ( $c f$. European Court of Auditors, 2012). According to the experience gained, these incentives in the countries of the region with more developed venture capital sector excessively increased the interest on the investors' side, thus decreasing the efficiency of public expenditure.

\section{Selection of private fund managers}

Public participation in venture capital schemes always carries the potential for abuse (Florida and Smith, 1993; Leleux et al., 1998). As a consequence of personal and political ties, and intentional abuse, the preferences many times do not reach the intended beneficiary companies, and so public funds are spent without any benefit to society as a whole. This is particularly the case for such arrangements, where no clearly set criteria apply and public investors are checked only rarely or even never.

Interestingly, in the evaluation of the Western experience with equity schemes, issues related to the selection of fund managers are rarely included as it would not be particularly problematic there.5 Murray et al. (2012) mentioned, as an important counter-argument against public equity schemes that, although the knowledge required for the selection of fund managers was not necessarily available within the authorities dealing with the tenders, in many cases they selected applicant teams with no relevant track record but which had managed government funds earlier (Murray et al., 2012). Since experienced professionals usually left hybrid funds and switched to the larger size private venture capital funds, this further decreased the probability of success for the investments made by hybrid funds.

Indeed, regulatory capture (i.e. when participants from the private and public sector primarily aim to acquire direct and indirect subsidies to be distributed by the state) is not unknown in the West, either. This is the case when the beneficiaries of the scheme will be the

\footnotetext{
5 The exception to this was the internationally recognised SBIC scheme from the US, serving as a reference model for public equity schemes in many Western states. The positive assessment of this scheme was not influenced by the fact that, according to Lerner (2002), political connections dominated the selection procedure over investment criteria. Therefore federal criminal investigations took place for some SBICs on the grounds of mismanagement, incompetence and fraud. According to an estimate cited by Kenney et al. (2004) nine out of ten SBICs violated official standards and dozens of companies committed crimes (Lerner, 2002; Kenney et al., 2004).
} 
acquaintances of the scheme managers of legislators (Lerner, 2014). In order to avoid political pressure in the selection of funds and portfolio companies involved in the scheme, a transparent decision-making process, similar to that customary in the private sector, is required (EC, 2012).

According to EU rules, fund managers intending to participate in equity schemes in the region had to compete for funds in public tenders. Theoretically, applications from foreign fund managers to the managed joint funds with the state were not excluded; however, in practice it was rather complicated in the absence of local knowledge. In the scheme launched by the Polish NCF, a foreign fund manager could win only on one occasion. The situation improved over time, since in a Polish BRIdge VC scheme published by the NCRD in 2014 foreign fund managers had already won both published positions (NCBIR, 2014). EIF also found a renowned regional fund manager as a winner in the Romanian JEREMIE programme.

When conducting the tenders, public holding funds usually scored the private fund managers tendering for public funds on the basis of a pre-set set of criteria. For the Polish NCF, the model for this was the method applied by the EBRD earlier, although the actual implementation, as shown by the interviews, did not necessarily follow the model. The promised quality of the portfolio to be set up was also included in the set of criteria, which obviously could have been the consequence of the funds' operation.

In several cases, the public procurement rules applicable in individual countries proved to be unsuitable for the tendering system for venture capital funds. The reason for the extension of tender evaluation announced by the Polish NCF to several years was that the state could commit itself only after the commitments by private participants, and it was difficult to maintain the interest of private actors for such an extended period of time (Rudnicka and Dietl, 2013). According to the Latvian public procurement rules, the winner had to be selected on the basis of the lowest price offered and this diverted the outcome of tenders from basic criteria, such as the business plan submitted by fund managers and the experience and expertise of fund managers i.e. the ability to pass professional knowledge to the future companies, in addition to the equity. By contrast, the management fee offered and the expected highest equity contribution received a greater emphasis in the evaluation (Avots et al., 2013). After the first round of JEREMIE, in 2012, the Latvian authorities launched another round, where, after the change of the holding fund's manager, the criteria were slightly restricted and a great number of experts were involved in the evaluation. At the same time, the evaluation continued to include many unclear criteria and so five tenderers challenged the award decision. As a follow-up, the court decided that the authority should not enter into the contracts and rewrite the draft contracts. However, this delayed the expected launch date of the funds by a year, leading to a very short investment period (Avots et al., 
2013). In the first round of the Hungarian JEREMIE programme, during the period between the publication of the scheme and the awards, the authority amended the terms of the call for tender, postponed the announcement of the award, then declared the tender unsuccessful and published a new one.

The background interviews with fund managers participating in the Hungarian JEREMIE tender and press news suggest a presumption that government ties could have meant an advantage, similarly to the public procurement in infrastructure, in winning funding. In the light of the owners as published in the press, amongst the 28 winning funds, government ties could have been assumed in 11 cases. Obviously one cannot exclude that the tender submitted by the fund managers concerned was not excellent from a professional point of view and their winning was a result of this (cf. Bruckner, 2012). The exclusion of government ties and proximity as a factor influencing the selection of winner was not always successful, even in Latvia (Avots et al., 2013).

The possibly biased or non-transparent selection of tenders in the region will not mean that successful fund managers with an experience gained in the region cannot be amongst the winners. Their number, however, was limited to begin with and so, in markets where many positions were published, newly established fund managers with no track record in venture capital could also win. Their senior managers took part in the competition, relying on their banking and corporate top management background rather than their track record in venture capital.

The expert interviews raised a unique regional problem i.e. that the legislation presumed the existence of fund managers who were independent from the investors; in practice, in many cases these two sets overlapped. The selection of the fund managers therefore meant granting a good position to the private investors behind the fund. This questions the practical importance of selecting fund managers with appropriate expertise and experience. Indeed, the decision is not made on the fund managers themselves but on the type and person of private investors joining the government. For example, the majority of fund managers in Hungary were not independent fund managers but so-called captive fund managers, i.e. belonging to the sphere of interest of a single investor. However, the tender rules contained no provision of any kind to restrict the individual proportion of private investors alongside the public investor.

In the management of public equity schemes in the region, a further problem was caused by changes occurring in the ownership and management of fund managers after winning the tender. Some of these were caused by the fact that the owner of the fund that won the position failed to make the committed contribution on the grounds of loss of interest and due to this the public funds already awarded to that fund had to be published again. It occurred that wealthy private individuals ran into trouble due to problems with their other businesses 
and thus they were forced to get rid of their investments in their venture capital funds and to transfer their funds to other private investors. The termination of the solvency of venture capital fund owners affected by the broker scandals which erupted in 2015 in the Hungarian market made the operation of some joint funds also impossible.

In the public equity schemes within the region, the tendering scheme was the actual scene for "fights" between the public and private sphere, and so all inadequately handled legal and interest issues, as well as the lack of transparency, culminated here. The authorities had not realised how important transparency is for trust and fruitful cooperation, and how harmful the design of scoring systems and the strictness in requiring compliance from applicants with formal elements of the tenders can be to later cooperation, which is based on counterdependencies. The possible corruption and the bias on the authorities' side became visible here for the profession and the public.

Private investors in public equity schemes

In a commercially operating regional or local venture capital market, the range of private owners investing in the funds already gives some indication on the range of investor groups that can be potential private investors in joining the public funds in public equity schemes within the countries of the region. According to the data published by the EVCA on the value of equity raised for venture and private equity investment in the region and the distribution of institutions providing the funds by type, between 2009 and 2013 it was the public bodies that provided equity in the highest proportion (39\%). The second investor group with the largest weight (19\%) was represented by the fund of funds, i.e. institutions that raised equity from other institutions for the purposes of investing it in venture capital funds. Lagging far behind are commercial banks (8\%) and pension funds (8\%), and insurance companies, corporations and wealthy private individuals with a $5 \%$ share each. The proportion of asset managers in the sources of the private venture capital funds of the region was $3 \%$ on average. The identity of the remaining $8 \%$ of those financing the value of the investments was not known by the data collectors (Höppner, 2014).

Since the size of the joint venture capital funds, capitalised with government funds was typically smaller, for them the natural investor partners are flexible institutions with good market information, managing smaller asset volumes (cf. Tillvaxtverket, 2011). Amongst them belong mainly institutions, foundations managing family assets and private venture capital funds. Amongst the non-institutional investors, business angels and wealthy private individuals provide the main source for the funds. According to the experience of the Western schemes, due to this latter group of investors, local knowledge and the relationship with local 
investors, inevitable for appropriate investment choices, are particularly important for the successful operation of hybrid funds (Tillvaxtverket, 2011).

However, the choices of hybrid venture capital funds between investors were largely constrained by the fact that there is a relatively low number of such investors in the region (cf. Szerb et al., 2007; Karsai, 2010; Klonowski, 2011). Due to the low number of family asset managers, foundations with assets to be invested and business angels ready to invest on a regular basis, the participants in the hybrid venture capital funds of the Central Eastern European region are typically wealthy private individuals.

The ownership data of venture capital funds established with joint public/private capital are not public in the region. On the basis of business and academic publications, the picture of private investors involved in public equity schemes is rather mixed. Where venture capital investments are allowed as diversification assets for pension funds and insurance undertakings, these institutions meant an actual choice for the role of a private investor in public equity schemes. This was the reason for example that, in the Baltic States institutional investors, and more precisely primarily pension funds, paid particular attention to hybrid schemes. At the same time it was problematic, even in the Baltic States, that the market proved to be too small for institutional investors. Big banks, when they wished to invest their assets in venture capital, did so in large fund of funds rather than in small size joint funds cofinanced by the government (Avots et al., 2013).

In the countries of the region where regulations did not allow the above institutions to invest their assets in venture capital funds, such as in the Bulgarian or Slovakian markets, it was much more difficult to find a well capitalised private investor for joint funds. At the same time, the capital volumes managed by private pension funds decreased, having a detrimental effect not only on the potential range of participants in public equity schemes but also by worsening the supply of funds in the venture capital market as a whole. This process started in Hungary, back in 2010, when most savings accumulated in private pension funds were channelled into the state pension scheme; but this trend also appeared in Bulgaria, Slovakia, Romania and Poland.

Out of the private investors in Latvian joint funds, corporate investors participated in a single fund, pension funds in four funds, banks in two funds, and private individuals in three funds (Prohorovs, 2014). The only Romanian joint fund was co-financed by the asset manager of a large bank. According to Polish expert interviews, the public equity scheme was exclusively joined by wealthy private individuals with their investments, and financing was undertaken by a foreign venture capital fund in a single case.

In Hungary, only one commercial bank was involved as investor in a joint fund. At the same time, amongst the owners of the funds, financial investor and broker groups were 
more frequent; these organisations can be found amongst the owners of eight JEREMIE funds. They supplemented their investment portfolio existing in other areas with venture capital. The other owners of Hungarian joint funds, that became known, were mainly wealthy individuals with an extensive track record in corporate ownership or top management. Amongst the investors, 13 out of the 100 wealthiest Hungarians participated in 18 funds out of the 28. It can be assumed that, for them, the possibility to acquire the funds allocated by the EU to the scheme was a very good business opportunity, as signalled by the oversubscription to the tender. Wealthy individuals, who earlier had not been interested in the venture capital market at all, also indicated their intention to participate. According to the one-off survey prepared by the National Bank of Hungary (NBH) in 2015, after the state, representing the highest share of the equity raised by the Hungarian JEREMIE venture capital funds (71\%), the contribution from wealthy private individuals (14\%) was the second most significant source of equity. Out of the total equity of the funds only $6 \%$ was provided by corporate investors, $5 \%$ by various asset managers and only $2 \%$ by banks. The remaining $4 \%$ came from types of investors, and the equity contributions from the fund managers themselves (NBH, 2015).

\section{THE EFFECT OF PUBLIC EQUITY SCHEMES ON THE VENTURE CAPITAL MARKET IN THE REGION}

The negative consequences of the crowding out effect on private actors' equity (cf. Leleux and Surlemont, 2003; Cumming and MacIntosh, 2006) did not have to be taken into account anywhere, since private investors were not or only occasionally interested in the financing of very early stage innovative companies. The venture capital supply of this market segment was previously met nearly exclusively by state-owned venture capital funds. In this way, the hybrid funds set up under this scheme meant competition to the incumbent fully state-owned funds and to each other. This latter effect appeared only in those few countries, such as in the Hungarian and Polish market, where a significant number of hybrid funds have been established due to the public equity schemes.

The supply of projects of a suitable quality was problematic everywhere in the region. Venture capital funds set up with public funds had to face, soon after their establishment, that there were not enough promising projects. In addition, a vast amount of investment offers were received by the hybrid venture capital funds in the region, a great proportion of which were not investment-ready, that is "ripe for investment". Projects ended up with venture capital funds in great numbers that they could not show an interest for. Namely, funds intended to invest in companies in a developed stage with a marketable and proven 
product where the target was only an even higher market penetration. However, there were only a few of this type of company in the region. Hence, it was not only the equity available for investment and the experienced venture capital professionals that were missing from the preconditions for the successful operation of government equity schemes, but also the activity of business angels, university business centres, incubators and business accelerator organisations, raising the projects up to the level when they are able to receive venture capital. ${ }^{6}$

The Western experience also highlighted that the state must allocate funds, in addition to the envisaged public venture capital schemes, education, preparation and promotional campaigns to ensure that the applicants present projects that are actually mature enough for investment. Looking at the cost/benefit side, training and supporting entrepreneurs with information proved to be much more efficient than the support provided to purchase machinery or equipment or facilitate manufacturing at an early stage (Keutschnigg and Nielsen, 2001, Mason and Kwok, 2012; Avots et al., 2013).

As regards success, it is an important question whether the further equity needs of promising projects can be ensured after the conclusion of the government schemes. It is an even more burning issue in the region, since it is still not very attractive to private venture capital investors in international comparison. Where the application of the model of public participation used in earlier programming periods goes on, then 2016-17, a nearly two year period, must be expected as one that must be survived without public equity, in view of the administrative processing time of compliance with EU rules. It might occur that a plan for setting up regional funds of a greater size with public funds takes shape, which is able to operate as fund of funds in the market of several countries, i.e. that finances private venture capital funds outside the national framework. The advantage of this solution would be that institutional investors who are unable to finance a smaller venture capital fund, due to its size, could join regional funds.

To a very different extent in each country, public equity schemes however increased the supply of venture capital to young, innovative SMEs. The public equity contribution generated interest from private investors towards a segment that was not attractive to it earlier. At the same time, the equity gap remained for very early stage projects in the seed capital stage and the preceding, so-called pre-seed phase. A significant learning process also took place in every market, including among the authorities and private market actors and the business providing the demand. At the same time, the schemes struggled with numerous

\footnotetext{
${ }^{6}$ In Hungary, the appearance of the hybrid JEREMIE funds "drove" the development of business development services and activated local business angels and the few private sector seed capital funds. In addition, the state launched a separate tender for the establishment of incubators; however, its start date was postponed due to the lack of funds actually transferred.
} 
issues already flagged by their Western predecessors and so they could have been prevented or mitigated.

The direct effect of the schemes on the economy can be measured via the increase in the number of financed businesses, the acceleration of their development, the creation of new jobs and the growing innovation performance. The analysis of the effects on companies can provide answers on the effectiveness of the work done by venture capital funds co-financed by the state; whether their companies became successful in business and at what return they were able to exit the investment. Since the actual investments by public equity schemes in the region started only post 2010, these questions can be answered only in a few years time. The future evaluations would be important, since Western surveys usually have not verified a stronger effect on innovation by public investment as opposed to private financing (Murray, 1998; Beroni and Tykvova, 2012, 2015), failed to demonstrate a significant revenue increasing role of public participation (Grilli and Murtinu, 2014) or its greater efficiency measured on the basis of expenditure (Alperovych et al., 2013). Additionally, the performance measured upon the exit of companies in receipt of public funds showed a mixed picture (Cumming and Johan, 2008, 2009, 2013; Buzzacchi et al, 2013; Croce and Ughetto, 2014).

\section{CONCLUSIONS}

This article examined the government's role as an investor in venture capital markets, through a detailed overview of the magnitude, forms and features of public participation, using examples from the CEE countries. It presented that, as opposed to the direct participation implying the risk of market distortion, CEE states contribute to raising funds in the venture capital market in a more indirect way, by involving the private sector. Theoretically, it is more successful in providing access to financing to early stage, risky but promising projects than the earlier fully public venture capital investments, that the selection is exempt from political influence, and that managers entrusted with the management of the investments have appropriate expertise and receive remuneration commensurate with their performance.

All in all, the experience suggests that the equity schemes launched by CEE states had all the positive and negative features that characterised similar schemes in developed countries. Countries in the region did not necessarily avoid the earlier mistakes; in some cases this was not made possible by the EU rules. In addition, the problems caused by the red tape involved in the operation of the EU and the national states were supplemented by the paternalistic and corrupt traditions of the region and the fact that cultural-institutional conditions cannot be 
changed from one day to the next. The avoidable typical mistakes included the extensive delays in decision-making, requiring more than half of the available time, and that government efforts exclusively aimed to increase the offer of venture capital and no demand side steps were taken, such as facilitating the establishment of incubation and accelerator organisations. The small size of the funds, unable to ensure efficient and self-sustaining operation, is also one of the known negative features. State restrictions on the size, geographical scope of investments and on the age of the financed companies raised a known problem, since these clearly worsened the efficiency and effectiveness of investments, and their circumvention in itself wasted resources.

The implementation of equity schemes however provided important knowledge to public bodies, strangers in the worlds of venture capital, in becoming aware of private investor attitudes, the assessment of the available potential resources and the operation of the incentive arrangements, and mapping the components to the lack of interest. This learning process was also useful for private investors since, in connection with the equity schemes, they could become aware of the criteria the government considers important and the standards of the European Union.

Compared to the Western experience, in Central Eastern Europe, the issues of finding and incentivising private investors in public equity schemes was even more pronounced. In the underdeveloped venture capital market of the region, the business angels, university foundations and smaller family asset managers potentially suitable for the role of co-investor, who could be interested in a joint investment with the state due to their size and expertise, were present to a lesser extent. The extensive preferences provided to private investors due to the lack of private investors in the markets of the region however resulted in wealthy private individuals, with publicly known strong connections to the public administration, taking up the role of the co-investor, and the lack of transparency allowed for the use of such connections when selecting fund managers. The biased selection of fund managers and the lack of experienced fund managers led to the dilution of the fund managers' market, since, in many cases, the primary objective of these less knowledgeable fund managers was exclusively to acquire public funds.

Although the schemes are not yet completed and their results are not completely measurable, the above issues suggest a waste of a significant part of community resources. The success of the scheme was already questioned by the fact that demand-side measures to facilitate the soundness of investment offers started late. The effect of the equity schemes will be reduced by the fact that, in some countries of the region, the venture capital market is unable to absorb the excess equity supply during the time available to use the Structural Funds, while a lack of equity will occur after the closure of the schemes. A further equity supply to the strengthened companies, financed jointly by public and private resources, 
seems to be not ensured. There are no funds of funds covering several countries in the region that could contribute to the financing of the venture capital funds established by public participation in another round.

Despite the above deficiencies and systemic issues, there were several positive effects in the venture capital market of the region. Thus, the significant increase in the equity supply in itself led to the creation of a few, outstandingly successful innovations. The awareness of venture capital as a corporate financing instrument has grown, and the operation of companies included in venture capital fund portfolios became much more transparent, resulting in the whitening of the economy in a very narrow scope. In connection with the opportunities offered by the scheme, the activity of business angels became more intense; a new range of private investors appeared in the segment of venture capital where earlier there was hardly any interest. Fund families have been created that are able to provide appropriate financing to projects with a perspective, by following their entire life cycle. Finally, as a consequence of the schemes, numerous new institutions appeared in the region that are able to assist in preparing professional investment proposals. As a result, the new financial engineering instruments based on public/private cooperation contributed to the modernisation of public venture capital schemes in the Eastern part of Europe.

However, a final assessment of the venture capital schemes in the CEE region cannot be made, and the outcome of the financed companies' development cannot be assessed. The lack of publicity and the merely formal evaluation of the programmes does not allow for an objective assessment of the results. Also, the efficiency measurement for the invested budget resources is missing. It continues to remain questionable how successful it was, in the public venture capital scheme framework, more modern than earlier, in actually transforming the state-focused and paternalistic approach, traditional to the region, according to the new approach. It is still to be seen whether the governments, while investing significant public funds coming from EU resources, were able to give up setting excessively detailed objectives, and to give preferential treatment, indirectly, to fund managers and the companies to be financed that are loyal to them. If and when this was so in individual cases, that would mean hidden state aid under the cover of venture capital. This would not only be questionable from the market competition point of view, but would also lead to the disappearance of the essential feature of venture capital, i.e. providing professional support to setting up successful companies. 


\section{REFERENCES}

Alperovych, Y., Hubner, G., Lobet, F. (2013). How (in)efficient is public venture capital? Evidence from Belgium. Working Paper, EMLyon.

Armour, J. \& Cumming, D. J. (2006). The legislative road to silicon valley. Oxford Economic Papers, 58, 596-635.

Avots, K., Strenga, K. \& Paalzow, A. (2013). Public venture capital in Latvia. Baltic Journal of Economics, 13 (1), 3-30.

Bertoni, F. \& Tykvova, T. (2012). Which form of venture capital is most supportive of innovation? ZEW. Discussion Papers, No. 12-018.

Bertoni,F. \& Tykvova, T. (2015). Does government venture capital spur invention and innovation? Evidence from young European biotech companies. Research Policy, 44(2015), 925-935.

Binder, I. (2009). Dice play (Kockajáték). Üzlet \& Siker, February. 24-26.

Brander, J. A., Egan, E. \& Hellmann, T. (20o8). Government sponsored versus private venture capital: Canadian evidence. In: Lerner, J., Schoar, A. (Eds.), International differences in entrepreneurship, Chapter 10. Chicago: University of Chicago Press.

Bruckner, G. (2012). The Töröcskeis' pocketed (Töröcskeiék taroltak). Figyelő.hu, 2012. 11. 08.

Buzzacchi, L., Scellato, G. \& Ughetto, E. (2013). The investment strategies of publicly sponsored venture capital funds. Journal of Banking and Finance, 37(3), 707-716.

Colombo, M. G., Cumming, D. J. \& Vismara, S. (2014). Governmental venture capital for innovative young firms. Journal of Technology Transfer, DOI 10.1007/s10961-0149380-9.

Croce, A. \& Ughetto, E. (2014). Dumping or taking on entrepreneurial ventures: The dynamics of switching between governmental and independent venture capitalists. Working Paper, Politechnico di Milano.

Cumming, D. J. \& Johan, S. A. (20o8). Information asymmetries, agency costs, and venture capital exit outcomes. Venture Capital: An International Journal of Entrepreneurial Finance, 10, 197-231.

Cumming, D. J. \& Johan, S. A. (2009). Pre-seed government venture capital funds. Journal of International Entrepreneurship, 7, 26-56.

Cumming, D. J. \& Johan, S. A. (2013). Venture Capital and Private Equity Contracting: An International Perspective, 2nd Ed., Elsevier Science Academic Press.

Cumming, D. J. \& MacIntosh, J. (2006). Crowding out private equity: Canadian evidence. Journal of Business Venturing, 21, 569-609.

Cumming, D. J., Grilli, L. \& Murtinu, S. (2014). Governmental and independent venture capital investors in Europe: A firm-level performance analysis. Journal of Corporate Finance (forthcoming). (http://dx.doi.org/10.2139/ssrn.2294746)

Dimov, D. \& Murray, G. (2006). The Determinants of the Incidence and Scale of Seed Capital Investments by Venture Capital Firms. University of Exeter. 18.08.2006. (http:www.sobe.ex.ac.uk/respapers/Dimo\&Murray_Mayo6.pdf.) 
$E C$ (2011). Communication from the Commission to the European Parliament and the Council. European Commission, 19.10.2011, COM(2011) 662 final.

EC (2012). Potential of Venture Capital in the European Union. Directorate General for International Policies. Policy Department A: Economic and Scientific Policy Industry, Research and Energy, 90 p.

EIF, (2014). Annual Report 2013. European Investment Fund. Luxemburg, 2014.

European Commission (2008). State aid N 355/2008 - Hungary. Hungarian JEREMIE risk capital measure. EC, Brussels, 10.12.2008.

European Commission (2012). State aid SA.34087 (2012/N) Hungary. New Széchenyi Risk Capital Programme - Modification of the Hungarian JEREMIE risk capital measure. EC, Brussels, 30.05.2012.

European Commission (2013). State Aid SA.36856 (2013/N) - Hungary. New Széchenyi Risk Capital Programme - Second modification of the Hungarian JEREMIE risk capital measure. Brussels, 22.7.2013.

European Court of Auditors (2012). Financial Instruments for SMEs. Co-Financed by the European Regional Development Fund, Special Report, No. 2, Luxemburg, 2012.

European Union (2014). Summary of data on the progress made in financing and implementing financial engineering instruments reported by the managing authorities in accordance with Article 67(2)(j) of Council Regulation (EC) No 1083/2006. European Commission, Directorate-General for Regional and Urban policy REGIO DG 02, Belgium. doi:10.2776/29238

EVCA (2010). Closing gaps and moving up a gear: The next stage of venture capital's evolution in Europe. EVCA Venture Capital White Paper, European Private Equity \& Venture Capital Association, Brussels, 2.3.2010. (http://iri.jrc.ec.europa.eu/concord2010/presentations/fricke.pdf)

Florida, R. \& Smith, D. F. (1993). Keep the Government out of Venture Capital, Issues in Science and Technology, 9, 61-69.

Grilli, L. \& Murtinu, S. (2014). Government, venture capital and the growth of European high-tech entrepreneurial firms. Research Policy, 43(9), 1523-1543. (http//dxdoi.org/10.1016/j.respol.2014.04.002)

Höppner, D. (2014): CEE Private Equity in the European Context. Presenatation of the EVCA Chief Executive. 16th Annual Conference of the Hungarian Pivate Equity and Venture Capital Association,. Budapest, 03.6.2014.

Karsai, J. (2003): What has the state got to do with the venture capital market? Public financing of Venture Capital in Hungary. Acta Oeconomica 53(3), 271-291.

Karsai, J. (2010): Private Equity in CEE. The Development of Venture Capital and Private Equity Industry in Central and Eastern Europe. VDM Verlag dr. Muller, Saarbrücken, 2010.

Karsai, J. (2013): Venture capital and Private Equity Industry in Hungary. Acta Oeconomica, 63(1), 23-42.

Karsai, J. (2014): Squering the circle? Government as venture capital investor. (Fából vaskarika? Az állam mint kockázatitőke-befektető.) Külgazdaság, 58(9-10), 3-34.

Kenney, M., Han, K. \& Tanaka, S. (2004). The Globalization of Venture Capital: The Cases of Taiwan and Japan. In: Bartzokas, A., Sunil Mani, S. (Eds.), Financial Systems, Corporate Investment in Innovation and Venture Capital. Cheltenham: UK and Northampton, MA: Edward Elgar: 52-83.

Keutschnigg, C. \& Nielsen, S. B. (2001). Public policy for venture capital. International Tax and Public Finance, 8, 557-572. 
KFK (2011). Investment policy. Favouring of private investors. Krajowy Fundusz Kapitalowy, $\quad$ 14.12.2011. $\quad$ (http://www.kfk.org.pl/en/print/how-weinvesrt/investment-policy)

Kitsing, M. (2013). Government as a Venture Capitalist: Evidence from Estonia. Mimeo, submitted to Industry Studies association Annual Conference, May 28-31, 2013. Tallin.

Klonowski, D. (2010). The effectiveness of government-sponsored programmes in supporting the SME sector in Poland. Post-Communist Economies, 22(2), 229-245.

Klonowski, D.(2011). Liquidity gaps in financing the SME sector in an emerging market: evidence from Poland. International Journal of Emerging Markets, 7(3), 335-355.

KPMG (2011). EU Funds in Central and Eastern Europe, Progress Report 2007-2010, KPMG Budapest.

Leleux B., Surlemont,B. \& Wacquier, H. (1998). State versus Private venture capital: cross Spawning or Crowding out? A Pan-European Analysis, Paper presented at the Babson College Kauffman Enterprepreneurship Research Centre, 1998.

Lerner, J. (2002).: When Bureaucrats Meet Entrepreneurs: The Design of Effective 'Public Venture Capital' Programmes, Economic Journal, Royal Economic Society, 112(477), F73-F84.

Lerner, J. (2009). Boulevard of Broken Dreams: Why Public Efforts to Boost Entrepreneurship and Venture Capital Have Failed and What to Do About it, Princeton: Princeton University Press, 2009.

Lerner, $J$. (2010). The future of public efforts to boost entrepreneurship and venture capital. Small Business Economics, 35(3), 255-264. DOI 10.1007/s11187-010-9298-z.

Lerner, J. (2014). Entrepreneurship, Public Policy, and Cities. Policy Research Working Paper, No. 6880, The World Bank, Sustainable Development Network, Urban and Disaster Risk Management Department, May 2014.

Mannick, K. (2007): Latvia: developing early-stage venture capital to sustain long-term economic growth.Technopolis Group, European Commission, Brussels.

Mason, C. M. (2013). Access to finance. A 'thought piece' for the North East LEP Independent Aconomic Review. Univerity of Glasgow, Adam Smith Business School, 11 March 2013.

Mason, C. M. \& Kwok, K. (2010).: Investment Readyness Programmes and Access to Finance: A Critical review of Design Issues. Local Economy, 25(4), 269-292. (doi:10.1080/02690942.2010.504570)

Meyer, T. (2007). The Public Sector's Role in the Promotion of Venture Capital Markets. SSRN 1019988, August, 2007.

Michie, R. \& Wishlade, F. (2012). Between Scylla and Charybdis: Navigating Financial Engineering Instruments Through Structural Funds and State Aid Requirements, IQNet Thematic Paper, 29(2), European Policies Research Centre.

MTI (2012). This year the state invests more money. (Idén több pénzt fektet be az állam.) Magyar Távirati Iroda, Budapest, nol.hu, 12.4.2012.

Murray, G. C. (1998). A Policy Response to Regional Disparities in Supply of Risk Capital to New Technology-based Firms in the European Union: The European Seed Capital Fund Scheme. Regional Studies, 32(5), 405-419.

Murray, G. C. (2007). Venture Capital and Government Policy. In: Landstrom, H. (ed.). Handbook of Research on Venture Capital . Cheltenham: Edward Elgar. 
Murray, G., Cowling, M., Liu, W. \& Kalinowska-Beszczynska, K. (2012). Government co-financed 'Hybrid' Venture Capital programmes: generalizing developed economy experience and its relevance to emerging nations. Kauffman International and Policy Roundtable, Liverpool, 11-12 March 2012.

Murray, G. \& Lingelbach, D. (2009). Twelve mediations on venture capital: some heretical observations on the dissonance between theory and practice when applied to public/private collaborations on entrepreneurial finance policy. University of Exeter Business School. Paper 06.09.2009.

$\mathrm{NBH}$ (2015). Analysis of the operation of domestic venture capital companies and funds (Elemzés a hazai kockázati tőkealap-kezelők és alapok működéséről.) Hungarian National Bank, Budapest, 02.2.2015.

NCBIR (2014). Launch of the largest high-tech venture capital fund in Poland. National Centre for Reasearch and Development, Warsaw, 20.2.2014. (http://www.ncbir.pl/en/news/art,2928,-launch-of-the-largest-high-tech-venturecapital-fund-in-poland)

Nicolaides, P. (2013). Financial Engineering Instruments and their Assessment under EU State Aid Rules. Bruges European Economic Policy Briefings, 2013/26.

Prohorovs, A. (2014). The Volume of Venture Capital Funds of Latvia and Their Financing Sources. China-USA Business Review, 13(4), 217-234.

Regeneris Consulting Ltd. (2013). Mid-Term Review of the English JEREMIE funds. Regeneris Consulting Ltd., London. (http: www.regeneris.co.uk.)

Rudnicka, B. \& Dietl, M. (2013). Public Support for Venture Capital in Emerging Markets: An Overview of Selected Countries. In: Klonowski, D. (ed.), Private Equity in Emerging Markets. The New Frontiers of International Finance (pp. 173-180). Palgrave Macmillan, New York.

Szerb, L., Rappai, G., Makra, Zs. \& Terjesen, S. (2007). Informal Investment in Transition Economies: Individual Characteristics and Clusters. Small Business Economics, 28(2-3), 257-271. (DOI 10.1007/s11187-006-9019-9)

Tillvaxtverket (2011). Mid-term evaluation of regional venture capital funds, Implementation and lessons learnt. Tillvaxtverket, Stockholm. (http://publikationer.tylllvaxtverket.se/ProductView.aspx?ID=1680)

Wilson, K. \& Silva, F. (2013). Policies for Seed and Early Finance. Findings from the 2012 OECD Financing Questionnaire. OECD Science, technology and Industry Policy Papers, No. 9., OECD Publishing, Paris. (http://dxdoi.org/10.1787/5k3xqsfooj33en).

Wilson, K. E. (2015). Policy Lessons from Financing Innovative Firms. OECD Science, Technology and Industry Policy Papers, No. 24, OECD Publishing, Paris. (http://dx.doi.org/10.1787/5jso3z8zrh9p-en).

Zsembery, L. (2012). Professional expert on the new Jeremie 2nd round. (Profi szakértő írása az új Jeremie II.-ről.) Insiderblog.hu, 13.6.2012. (http://Insiderblog.hu/blogzine/2012/o6/13/profi-szakerto-irasa-az-uj-jeremie-ii$\mathrm{rol} /$ ) 